UDC 373.3/.5.091.212.012+37.013.75](091)(477)"189/194"

Oleksandr Mikhno

ORCID iD 0000-0002-5271-9530

$\mathrm{PhD}$ (Pedagogy), Senior Researcher of the Sukhomlynistics Sector of the Pedagogical Source Studies and Biographistics Department, V. O. Sukhomlynsky State Scientific and Pedagogical Library of Ukraine, 9 M. Berlinsky Str., 04060 Kyiv, Ukraine, amihno@ukr.net

\title{
CHARACTERISTIC OF A STUDENT IN EXPERIMENTAL PEDAGOGY BY O. NECHAEV AND G. ROSSOLIMO
}

In the article, based on the analysis of the works of scientists - the representatives of experimental pedagogy Olexandr Nechaev (1870-1947) and Grigory Rossolimo (1860-1928), their contribution to the development of the problem of the pupil's profile is highlighted. It has been proved that both scientists paid special attention to this issue, developing it in the following aspects: substantiation of the necessity of studying a pupil by the teacher and improvement of psychological knowledge of the teacher (O. Nechaev); creation of plans for studying the pupil in the form of special questionnaires with detailed recommendations on their use (O. Nechaev, G. Rossolimo), filling out the results of studying the pupil in the form of «psychological profile», which was a graphic representation of the profile (G. Rossolimo). It has been substantiated that, developing a problem of the pupil's profile, $O$. Nechaev proceeded from the need to take into account the individual abilities and inclinations of the pupil in the educational process, which could be effectively carried out on the basis of studying the pupil with the subsequent compilation of the pupil's profile. It has been well-reasoned that relations between scientists were significant in the development of scientific ideas: G. Rossolimo linked the emergence of his method of «psychological profile» directly with the ideas of O. Nechaev. It has been emphasized that the psychological characteristics of various types given by Rossolimo were his contribution to the typology of childhood, along with the typology of $P$. Lesgaft. These typologies are a significant help to the teacher in the process of learning the pupil and compilation of his profile. It has been emphasized that experimental pedagogy is a scientific phenomenon, the name of which reflects the main method of obtaining empirical knowledge - an experiment that was supposed to guarantee the objectivity of the data obtained, bringing pedagogy to the level of exact sciences; the concept of «experimental pedagogy» is established within the limits of historical-pedagogical discourse as a definition of the scientific phenomenon, characteristic only for the beginning of the XX century.

Key words: experimental pedagogy; Grigory Rossolimo; layout of a profile, Olexandr Nechaev; pupil's profile.

https://doi.org/10.28925/1609-8595.2020.1.9

Introduction. One of the main conditions for the progress of society is the modernization of the educational and training systems. Effectiveness of this modernization is intended to provide pedagogical science, an important source of development, which is mastering the achievements of the past with the transformation of the history of pedagogy into one of the most important units of scientific and pedagogical knowledge. At the end of XIX - beginning of XX century. Ukraine and the world have had a successful experience of developing new pedagogy and reforming its education system. The motive force of change was experimental pedagogy at that time. We regard it as a scientific phenomenon, the name of which reflects the basic method of obtaining empirical knowledge, an experiment that was intended to guarantee the objectivity of the obtained data, bringing pedagogy to a new level of exact sciences. It should be noted that the term of «experimental pedagogy» is established within the framework of historical and pedagogic discourse as a definition of a scientific phenomenon, typical only for the beginning of the XX century. At the edge of the nineteenth and twentieth centuries experimental pedagogy has gained worldwide popularity. Among its representatives are, first of all, A. Binet, J. David, E. Clapared, V. Kilpatrick, V. Lai, E. Meiman, M. Montessori, E. Thorndike, A. Ferrier, S. Hall, and others. Among the national scientists of this area are O. Lazursky, O. Nechaev, G. Rossolimo, I. Sikorsky and others.

The problem of experimental pedagogy was studied by Ukrainian and foreignscientisits: B. Wolfson, S. Goncharenko, N. Ditchek, L. Lysenko, V. Lukyanov, A. Romanov, O. Sukhomlinskaya, T. Yanchenko, and others. Although they considered the features of experimental pedagogy, the evolution of its influence on the theory and practice of schooling had been deduced, 
a number of problems that are part of the experimental pedagogy phenomenon still remain unanswered.

These include the problem of student characteristic in the heritage of scientists - representatives of experimental pedagogy.

The purpose of the article - on the basis of the analysis of the works of Olexandr Nechaev (1870-1947) and Grigory Rossolimo (1860-1928) to highlight their contribution to the development of the problem of student characteristic. To achieve this goal, we used scientific and methodological tools, based on systematic, historical, logical, anthropological and methodological approaches and general scientific methods of theoretical analysis, synthesis, abstraction, concretization, generalization.

The literature review and findings. The research of one of the founders of experimental pedagogy Olexander Nechaev was devoted to the problems of attention, fatigue, schoolchildren's suggestibility, visual memory, and associations of children aged 3 to 10 years. The scientist held experimental work in public schools, classical gymnasiums, real and commercial specialized schools, cadet corps. Respondents could be up to several hundred students from different educational institutions at the same time. Working at the St. Petersburg's Pedagogical Museum of the Military Training Office, O. Nechaev had the opportunity to develop a new direction in psychology. He succeeded in acquiring the psychological instruments ordered by his own drawings in Germany, acommercial equipment, which led to the opening of the first laboratory of experimental pedagogical psychology in Russia. The first official success and recognition of O. Nechaev's works refer to 1903, when the International Children's World exhibition was held in St. Petersburg, where basic psychological apparatus, used in the study of children, and diagrams depicting the results of experiments were presented. For them, the scientist and his laboratory received two gold medals. In addition, in the journal «Russian School», he edited a special section devoted to the materials and articles on childhood psychology and experimental pedagogy (Nechaev, 1899, 1902).

In 1906 O. Nechaev defended his dissertation «Similarity Association» for the master's degree in philosophy at the Odessa University. The defense was supported by M. Lange, who in 1896 opened the first laboratory of experimental psychology in the Russian Empire (Kuznetsova and Kuznetsov, 2016, p. 15).

Experimental pedagogy has gained recognition mainly through the organization of All-Russian congresses. In total, up to 1916 , there were 5 congresses that are commonly called to in the scientific literature as psychological. The first two ones were called Congresses of Educational Psychology, the next three were Congresses of Experimental Pedagogy.

The construction of new pedagogy required the development of its methodological foundations. Figures of experimental pedagogy set the aim to study the child in as it called parallelism of his mental and physical development, because only in this case we could speak about the comprehensive development of the child. The teacher should not be satisfied with the knowledge of the separate phenomena of students' mental life, but should be aware of the general essence of the child's development. Understanding the nature of such development determines the construction of the whole educational and training systems, and «the basic rule for any teacher should be the requirement to study the spiritual life of their pupils. It has long been recognized by all prominent educators who (such as the English thinker Locke, the German educator Herbart and Konstantin Ushinsky) were usually also profound psychologists» (Nechaev, 1916, p. 11).

Nechaev (1911) emphasized that the school, seeking to give students a general education and to lay the ways to «create a holistic worldview of students», cannot fail to take into account their individual abilities and predisposition. In this regard, the scientist developed the problem of describing of the student, which is fully justified in the book «Essay on psychology for educators and teachers». It contains a separate section on character and, in which Nechaev (1911) substantiates the importance of compiling student characteristic. To «describe» a person means to observe his actions, to depict his interests, dominant moods and inclinations» (p.336).After, theauthorprovidestheoreticalinformation about the achievements of pedagogy and psychology in the study of the student, in particular, notes that the character of a person is determined, first, depending on the peculiarities of his body (the physiological basis of the character, emphasizes the scientist, called temperament) and, second, from environmental impact (the sum of all external irritants). It is the external influence, that is, educating and training, that is the force capable of forming a coherent personality. With regard to the problem of heredity, from the pedagogical point of view, according to Nechaev (1911), the following notes are important: hereditary predisposition to certain emotional experiences, not whole characters, is transmitted; simple skills are inherited more often than complex talents; along with the influence of heredity, strongly influences the development of mental life and environment (p. 340).

Thus, Nechaev (1911) emphasizes, that for the proper organization of the educational process of the teacher it is important to constantly monitor the mental development of students, to be aware of their individual characteristics. The author notes that under the influence of the spread of psychological knowledge among teachers in many educational establishments, attempts are already being made to describe students, but these attempts in most cases prove to be unsatisfactory.

For appropriate observation of the mental life of the student first requires some general psychological training. However, because of the absence of special departments of psychology at universities and poor development of psychological laboratories, pedagogues 
are usually either completely ignorant of psychology or extremely superficial. School doctors, who in the case of compiling student characteristic could be pedagogues' assistants, also do not have psychological training. Such a state of affairs, according to the scientist, requires immediate changes, namely: all measures should be taken to increase the level of psychological knowledge of teachers and school doctors (p. 342).

At the end of the section Nechaev (1911) added an appendix to help the teacher in the characteristic process, which contains 10 page marking questions, where the teacher can find more detailed explanations of each question. We consider this appendix as a form of a questionnaire as a structure of student characteristic in Nechaev's vision:

«What is your current state of health now?

Did you suffer from serious illnesses in childhood?

Were there any cases of mental and nervous illness, alcoholism, tuberculosis and other serious illnesses in the family?

What types of memory are most developed?

What forms are mental activity and fatigue are shown up?

Is attention sustained and predominantly external or internal?

Is it suggestive?

What are the forms of dominant sentiment?

Do they have a one-sided nature? What are the processes of judgment?

How evident psychic life coherence and integrity principles in the child are?» (p. 343).

Thus, developing the problem of student characteristic, Nechaev (1911) went from the need to take into account individual abilities and inclinations of the student in the educational process, which is effectively accomplish on the basis of teacher's study of the student with the subsequent compilation of the student's characteristic. These ideas of Nechaev (1911) were echoed by his contemporaries, which undoubtedly influenced the further development of experimental pedagogy. Let us elaborate this thesis.

There is afactor that is sometimes difficult to document in the history of every science, including pedagogy, but which is undoubtedly significant in the development of scientific ideas. It is the relationships between scientists that are often contradictory and complex. Nechaev (1911) did not always find support for his scientific ideas (this is evidenced, in particular, by his long discussion with G. Chelpanov on methods of studying the student and the place of experiment among these methods), but with his persistent activity he actively contributed to the development of experimental pedagogy and pedagogical psychology. With endless energy, he was able to inspire experimental pedagogy of scientists, doctors and educators: O. Lazursky, V. Vakhterova, G. Rossolimo and many others. Thus, O. Lazursky wrote in a letter to his brother: «I want to organize, together with O. Nechaev (psychologist and teacher), systematic observations of students and adolescents in different boarding schools and educational establishments in order to obtain detailed characteristics drawn up in one general plan». And further: «... we are testing experimental methods that allow us to study individual features of memory, attention, perception, imagination, etc. And when it is enough material from the cadet corps, we will compile the characteristics. In my opinion, the study of individuality should be the main task of the immediate future» (Romanov, 2010, p. 47). Rossolimo linked the emergence of his method of «psychological profile» directly with the ideas of Nechaev (see: Romanov, 1996, p. 47).

Rossolimo (1906) paid special attention to the development of methods of experimental and psychological research, the study of psychology of personality, the role of hereditary and innate in its mental development, its age peculiarities. The direct contribution of the scientist to the development of the problem of characterization of the student is his work «Plan of the study of the child's soul. A Guide for Parents and Teachers» (Rossolimo, 1906). In the preface, the author writes: «The proposed «Plan», which is intended to serve as a guide in drawing up a child's characteristics using the observation method, can also help parents who care about the child's proper development and the teacher who needs a proper assessment of the student's success. in children's mental mechanics, and a physician who often addresses the information gathered about him in family and school circumstances during his study of the child» (p. 3).

In his «Plan» Rossolimo (1910) recommended to: 1) give an unprejudiced answer to picture the child's soul correctly, 2) give a short and at the time full answers, 3) preferably add a photo of a child, example of handwriting and drawings, 4) it is desirable to periodically update the characteristics in order to obtain from the consistent series of such characteristics a «relief history of personality development». The structure of the plan was explored in detail by Kolomiets (2015), who summarized numerous issues in 8 sections: 1) family characteristics; 2) family education; 3) home study; 4) schools; 5) characteristics of the baby's soul; 6) history of development and growth; 7) health history; 8) causes of disorders of the nervous system (p. 141-142). Moreover, each section is specified in detail. For example, the characterization of the soul of the child provides answers to the following questions: «development of intelligence, its compliance with standards, ingenuity, cognitive activity; dominant memory type, memory features, storage of information, accuracy of its reproduction; imagination, fantasy; attention, attentiveness, attention span, concentration and focus; overall level of abilities, inclination, influence on academic achievement; literacy, perfection of spoken and written speech; success in various activities (training, drawing, modelling, etc.); feelings, spiritual mood, tendency to affect, unmotivated fears, religious, moral, aesthetic feelings, attitude to one's own sex; will, energy, perseverance, sense of duty, obedience, 
industriousness, aptitude for deviant behavior, unclear and impulsive actions, etc». Let us add that Rossolimo's plan was the most adapted for use by parents, teacher and school doctor, since it was built on the principle of «question - answer», had special places (several lines after the question), which contained information, glued photos of the child, her drawings, samples written works, etc.

As an innovator in the implementation of experimental methods in psychology and pedagogy, Rossolimo (1910) simultaneously with Lazursky persistently sought such a method of research of the psyche, which would enrich the theory, give noticeable practical results and thus serve the purpose of practice. In his opinion, such a method should consist of a specific test system, which would cover all the basic mental processes, would allow them to quantify and measure them. From 1908 to 1928 Rossolimo (1910) worked on the creation and improvement of such a method, which he called the method of psychological profiles. Through individual 38 tests, the scientist explored 11 mental processes (attention, will, accuracy of perception, visual memory, memorization of elements of language, numbers, comprehension, combinatorial ability, ingenuity, imagination, observation). Under Rossolimo's (1910) profiles, he understood the way of presenting the results of psychological research in the form of graphic images (profiles) through the connection of the highest numerical points obtained in the study of a particular personality trait (Fig. 1). The essence of the method of psychological profiles Rossolimo clearly and comprehensively described researcher Petukhova (2013): «Each of the studied cognitive and emotionalvolitional mental processes was fixed on the axis of ordinates. On the abscissa axis, the researcher recorded the level of development for each mental process, which had indicators from one to ten: 1 - minimum, 10 - maximum. At the end of the study, all points in the graph were connected by a single line, which represented a detailed psychological profile that demonstrated the strengths and weaknesses of the mental development of the child's personality» (p. 298).

In our opinion, by the method of psychological profiles G. Rossolimo introduced in the development of the problem characteristics of the student such positive tendencies as the quantitative measurement of the level of formation of mental processes and graphical analysis of the results. Rossolimo Profiles, along with Lazursky Stars, is a visual (graphic) representation of the characteristic (for Lazursky Stars see: Mikhno, 2019, pp. 58-59).

\section{A- fine \\ C-significantly retarded \\ B-slightly retarded D- stupidity}

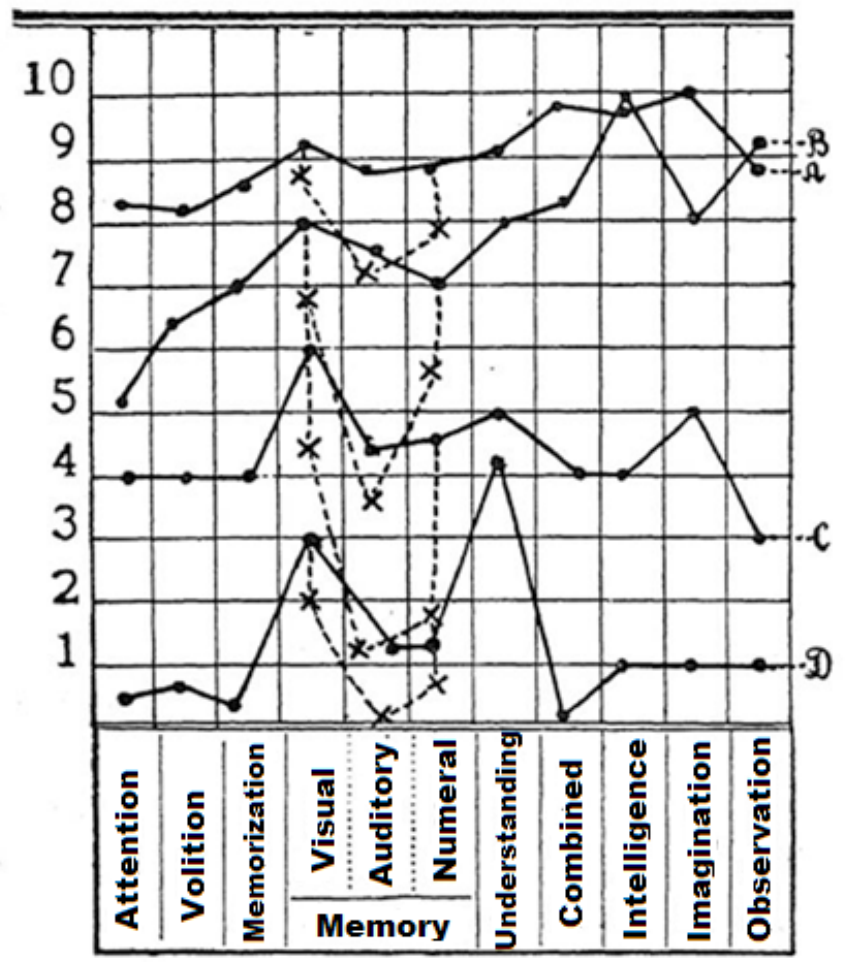

Figure 1. Psychological profile of Rossolimo (Rossolimo, 1910, p. 48)

Using a variety of research methods, Rossolimo tried to build a classification of types of human nervous activity and to give their psychological and physiological characteristics. By the nature of the ratio of the degrees of development of different mental processes, it distinguishes 7 main types: 1) positive type, which develops uniformly intellectual, volitional and emotional processes, 2) hypotonic - with weakened will and attention, 3) amnestic - with relative weakness of receptiveness, 4) dementia - with relative insufficiency 
of higher processes (thinking, ingenuity, ability to generalize, etc.), 5) psychasthenia - with relatively reduced will, attention and memory in comparison with higher processes, 6) hypotensive-dementia - with relatively high development of memory 7) mysticismdementia - with relatively high attention and will, but reduced memory processes and higher thinking abilities (Marisova, 1959, p. 202). Indeed, there are students in whom natural memory helps them to think less and express others' thoughts by heart; there are also schoolchildren in whom developed thinking is combined with weakness of will and so on. The psychological characterization of the different types given by Rossolimo is his contribution to the typology of childhood along with the typology of P. Lesgaft. These typologies are a significant help to the teacher in the process of student learning and characterization.

We emphasize another aspect that we consider important from a pedagogical point of view, namely, the study of fear by the scientist and his role in the educational process. In his article, Fear and Education, he first considers the emotion of fear as an innate reflexive, unconscious reaction to the danger inherent in all people. This reaction is very important in life and is accompanied by significant physiological changes in the body. But the frequent repetition of fear experiences leads to the gradual emergence and development of timidity, and the degree of its development depends on the individual characteristics of the child, on the greater or less vulnerability of its nervous system (Rossolimo, 1897). The article deals with various types of fear: 1) logical fear (fear of death, fear of big animals, everything dangerous to life), 2) illogical fear (fear of small animals, insects, fear of darkness, water, etc.) and 3) obsessive fears or phobias. Parenting, built on different methods of bullying, gradually leads to the logical fear becomes illogical and even intrusive, the habit of fearing everything, especially in children with weak or weak nervous system. Rosolimo (1897) gives some psychological advice on how to avoid anything that can give the child reason to fear, severely criticizes those griefeducators who consider fear as the basis of educational work. The psychological analysis of the emotion of fear given by Rossolimo (1897), the revelation of typological manifestations and conditions for the emergence of such a trait as timidity, and still does not lose its scientific value (Rossolimo, 1897; Marisova, 1959, p. 202).

Conclusions. Thus, the representatives of experimental pedagogy Nechaev and Rossolimo made a significant contribution both in substantiating the need to study the student with the subsequent compilation of the characteristic (O. Nechaev), and in the methodology of composing the characteristic by offering special questionnaires, which were valuable guidance for the teacher the process of writing a feature. Moreover, the problem of characterization was considered by scientists holistically in various aspects: from the need to increase the psychological knowledge of the teacher (O. Nechaev) to the development of a plan of study of the student, which was at the same time the structure of the characteristic. In addition, Rossolimo proposed a fundamentally new way of designing the results of the student's study in the form of «psychological profile», which was a visual (graphic) representation of the characteristic.

Supporting the opinion of modern researchers that «the basic principles of experimental pedagogy was the basis of domestic pedagogy» (Bashkir, 2017, p. 65), the prospect of further scientific research determines the study of the impact of experimental pedagogy on the formation and development of pedagogy in Ukraine in 1920-1930.

\section{References}

Bashkir, O. (2017). Mistse pedahohiky v systemi pedahohichnoi osvity Ukrainy v istorychnomu dyskursi XIX pochatku XX st. [The Place of Pedagogics in the System of Pedagogical Education of Ukraine in the Historical Discourse of in the 19th - early 20th centuries]. Osvitolohichnyi dyskurs, 3-4 (18-19), 57-70. https://doi. org/10.28925/2312-5829.2017.3-4.570.

Kolomiiets, L. I. (2015). Shchodennykovi sposterezhennia yak metod doslidzhennia psykhichnoho rozvytku ditei $\mathrm{v}$ istorii eksperymentalnoi pedahohiky kintsia XIX - pochatku XX st. [Observation diary as a method of researching children's mental development in the history of experimental pedagogy of the late 19th - early 20th centuries]. Naukovyi visnyk Khersonskoho derzhavnoho universytetu: zbirnyk naukovykh prats. Psykholohichni nauky, 1 (1), 139-144.

Kuznetsova, N. V. \&Kuznetsov, V. O. (2016). Rol uchenykh Odeskoho (Novorosiiskoho) universytetu u stanovlenni y rozvytku eksperymentalnoi psykholohii: M. Ya. Groth, M. M. Lange, G. I. Chelpanov [The role of scientists of the Odessa (Novorossiysk) University in the formation and development of experimental psychology: M. Ya. Groth, M. M. Lange, G. I. Chelpanov]. Mizhnarodni Chelpanivski psykholoho-pedahohichni chytannia (pp. 7-20). Hnozis.

Marysova, L. I. (1959). H. I. Rossolimo yak psykholoh [Rossolimo as a psychologist]. In Narysy zistorii vitchyznianoi psykholohii kintsia XIX - pochatku XX st. (pp. 189-204).

Mikhno, O. (2019). Naukova kharakterolohiia Oleksandra Lazurskoho yak vnesok u metodyku skladannia kharakterystyky uchnia [Scientific characterology by Olexandr Lazursky as a contribution to the pupil's characterization methodology]. Ridnashkola, 1, 53-60.

Nechaev, A. P. (1899). K voprosu o vzaimootnoshenii pedagogiki i psihologii [On the question of the relationship between pedagogy and psychology]. Russkaja shkola, 3, 45-51. 
Nechaev, A. P. (1902). Ob organizacii psihologicheskih nabljudenij [About the organization of psychological observations]. Russkaja shkola, 2, 149-154.

Nechaev, A. P. (1911). Ocherk psihologii dlja vospitatelej i uchitelej [Psychology essay for educators and teachers]. Tipografiya P. P. Sojkina.

Nechaev, A. P. (1916). Kurs pedagogicheskoj psihologii dlja narodnyh uchitelej [The course of pedagogical psychology for the national teachers]. Tovarishestvo «V. V. Dumnov, nasledn. Bratev Salaevyh».

Pietukhova, I. O. (2013). Pohliady dorevoliutsiinykh doslidnykiv na psykholoho-pedahohichnu diahnostyku rozumovykh zdibnostei [The views of prerevolutionary researchers' psycho-pedagogical diagnosis of mental abilities]. Visnyk Luhanskoho natsionalnoho universytetu imeni Tarasa Shevchenka. Pedahohichni nauky, 10 (4), 297-303.

Romanov, A. A. (1996). A. P. Nechaev: u istokov jeksperimental'noj pedagogiki [A. P. Nechaev: at the origins of experimental pedagogy]. ROU.

Romanov, A. A. (2010). Vospitanie nravstvenno cennoj lichnosti (k 140-letiju so dnja rozhdenija A. P. Nechaeva) [The education of a morally valuable personality (on the 140th anniversary of the birth of A. P. Nechaev)]. Mir obrazovanija - obrazovanie v mire, 2, 44-51.

Rossolimo, G. I. (1897). Strah i vospitanie [Fear and education]. Voprosy nervno-psihicheskoj mediciny, 2, 593-607.

Rossolimo, G. I. (1906). Plan issledovanija detskoj dushi. Posobie dlja roditelej i pedagogov [Study plan of the child's soul. Manual for parents and teachers]. Tipolitografiya tovarishestva I. N. Kushnerevi K.

Rossolimo, G. I. (1910). Psihologicheskie profili. Chast' 1: Metodika [Psychological Profiles, Part 1: Methods]. Tipografiya M. A. Aleksandrova.

\section{Література}

Башкір О. Місце педагогіки в системі педагогічної освіти України в історичному дискурсі XIX -початку XX ст. Освітологічний дискурс. 2017. № 3-4 (18-19). С. 57-70. DOI: https://doi.org/10.28925/23125829.2017.3-4.570.

Коломієць Л. І. Щоденникові спостереження як метод дослідження психічного розвитку дітей в історії експериментальної педагогіки кінця XIX - початку XX століття. Науковий вісник Херсонського державного університету: збірник наукових пращь. Психологічні науки. 2015. № 1. Т. 1. С. 139-144.

Кузнецова Н. В., Кузнецов В. О. Роль учених Одеського (Новоросійського) університету у становленні й розвитку експериментальної психології: М. Я. Грот, М. М. Ланге, Г. І. Челпанов. Міжнародні Челпанівські психолого-педагогічні читання. Київ: Гнозіс, 2016. С. 7-20.

Марисова Л. Й. Г. І. Россолімо як психолог. Нариси з історії вітчизняної психологї кіния ХІХ і початку ХХ cm. / За ред. Г. С. Костюка. Київ: Радянська школа, 1959. С. 189-204.

Міхно О. Наукова характерологія Олександра Лазурського як внесок у методику складання характеристики учня. Рідна школа. 2019. № 1. С. 53-60.

Нечаев А. П. К вопросу о взаимоотношении педагогики и психологии. Русская школа. 1899. № 3. С. $45-51$. Нечаев А. П. Об организации психологических наблюдений. Русская школа. 1902. № 2. С. 149-154.

Нечаев А. П. Очерк психологии для воспитателей и учителей. Санкт-Петербург: Типография П. П. Сойкина, 1911. 352 с.

Нечаев А. П. Курс педагогической психологии для народных учителей. Петроград: Товарищество «В. В. Думнов, наследн. Братьев Салаевых», 1916. 184 с.

Пєтухова I. О. Погляди дореволюційних дослідників на психолого-педагогічну діагностику розумових здібностей. Вісник Луганського національного університету імені Тараса Шевченка. Педагогічні науки. 2013. № 10 (4). C. 297-303.

Романов А. А. А. П. Нечаев: у истоков экспериментальной педагогики. Москва: РОУ, 1996. 81 с.

Романов А. А. Воспитание нравственно ценной личности (к 140-летию со дня рождения А. П. Нечаева). Мир образования - образование в мире. 2010. № 2. С. 44-51.

Россолимо Г. И. Страх и воспитание. Вопросы нервно-психической медищины. 1897. Т. 2. С. 593-607.

Россолимо Г. И. План исследования детской души. Пособие для родителей и педагогов. Москва: Типолитография товарищества И. Н. Кушнерев и К우 1906.90 с.

Россолимо Г. И. Психологические профили. Часть 1: Методика. Санкт-Петербург: Типография М. А. Александрова, 1910.52 с. 


\section{ХАРАКТЕРИСТИКА УЧНЯ В ПРАЦЯХ ПРЕДСТАВНИКІВ ЕКСПЕРИМЕНТАЛЬНОЇ ПЕДАГОГІКИ О. НЕЧАЕВА ТА Г. РОССОЛІМО}

Міхно Олександр, кандидат педагогічних наук, старший науковий співробітник сектору сухомлиністики відділу педагогічного джерелознавства та біографістики, Державна науково-педагогічна бібліотека України імені В. О. Сухомлинського, вул. М. Берлинського, 9, 04060, Київ, Україна, amihno@ukr.net

У статті на основі аналізу пращь учених - представників експериментальної педагогіки Олександра Нечаєва (1870-1947) та Григорія Россолімо (1860-1928) висвітлено іхній внесок у розроблення проблеми характеристики учня. Доведено, що обидва вчені зазначеній проблемі приділяли особливу увагу, розробляючи ї̈ у таких аспектах: обгрунтування необхідності вивчення вчителем учня та підвищення психологічних знань учителя (О. Нечаєв), створення планів вивчення школяра у формі спеціальних питальників з детальним рекомендаціями щодо користування ними (О. Нечаєв, Г. Россолімо), оформлення результатів вивчення учня у виглядi «психологічного профілю», що був наочним (графічним) зображенням характеристики (Г. Россолімо). Устатті обгрунтовано, що, розробляючи профіль учня, О. Нечаєв виходив з необхідності враховувати індивідуальні здібності та схильності вихования в навчальному процесі, які можна було б ефективно здійснити на основі вивчення учень з подальшим складанням профілю учня. Акцентовано, що стосунки між вченими були важливими у розвитку наукових ідей: Г. Россолімо пов’язував виникнення свого методу «психологічного профілю» безпосередньо з ідеями О. Нечаєва. У висновках підкреслено, що психологічні характеристики різних типів, розроблені Россолімо, були його внеском у типологію дитинства, поряд із типологією П. Лесгафта. Ці типології є вагомою допомогою вчителя в прочесі навчання школяра та складання його профілю. Акцентовано, що експериментальна педагогіка - це науковий феномен, назва котрого відображає основний метод отримання емпіричних знань експеримент, який мав гарантувати об'єктивність отриманих даних, виводячи педагогіку на рівень точних наук.

Ключові слова: Григорій Россолімо; експериментальна педагогіка; Олександр Нечаєв; структура характеристики; характеристика учня.

\section{ХАРАКТЕРИСТИКА УЧЕНИКА В ТРУДАХ ПРЕДСТАВИТЕЛЕЙ ЭКСПЕРИМЕНТАЛЬНОЙ ПЕДАГОГИКИ \\ А. НЕЧАЕВА И Г. РОССОЛИМО}

Михно Александр, кандидат педагогических наук, старший научный сотрудник сектора

сухомлинистики отдела педагогического источниковедения и биографистики,

Государственная научно-педагогическая библиотека Украины имени В. А. Сухомлинского,

ул. М. Берлинского, 9, 04060 Киев, Украина, amihno@ukr.net

В статье на основе анализа трудов ученых - представителей экспериментальной педагогики Александра Нечаева (1870-1947) и Григория Россолимо (1860-1928) отражен их вклад в разработку проблемы характеристики ученика. Доказано, что оба ученые указанной проблеме уделяли особое внимание, разрабатывая ее в следующих аспектах: обоснование необходимости изучения учителем ученика и повышение психологических знаний учителя (А. Нечаев), создание планов изучения школьника в виде специальных опросников с подробным рекомендациям по их использованию (А. Нечаев, Г. Россолимо), оформление результатов изучения ученика в виде «психологического профиля», который был наглядным (графическим) изображением характеристики (Г. Россолимо). Акцентировано, ито экспериментальная педагогика - этонаучный феномен, названиекоторого отражаетосновнойметод полученияэмпирических знаний - эксперимент, который должен был гарантировать объективность полученных данных, выводя педагогику на уровень точных наук.

Ключевые слова: Александр Нечаев; Григорий Россолимо; структура характеристики; характеристика ученика; экспериментальная педагогика. 